\title{
Pengembangan Edible Film Komposit Berbasis Pati Jagung dengan Penambahan Minyak Sawit dan Tween 20
}

\author{
Development of Composite Edible Film Based on Corn Starch with Addition of Palm Oil and Tween 20
}

\author{
Budi Santoso*, Debby Amilita, Gatot Priyanto, Hermanto, Sugito \\ Program Studi Teknologi Hasil Pertanian, Jurusan Teknologi Pertanian, \\ Fakultas Pertanian, Universitas Sriwijaya, Jl. Raya Palembang-Prabumulih Km. 32, \\ Indaralaya, Ogan Ilir, Propinsi Sumatera Selatan, 30862 Indonesia \\ Email: budiunsri@yahoo.com
}

Tanggal submisi: 11 November 2017; Tanggal penerimaan: 3 Mei 2018

\begin{abstract}
ABSTRAK
Penelitian ini bertujuan untuk mengetahui karakteristik edible film komposit berbasis pati jagung yang dinkorporasikan dengan minyak sawit dan Tween 20. Rancangan penelitian yang digunakan adalah rancangan acak lengkap faktorial (RALF) dengan dua faktor perlakuan yang setiap perlakuannya diulang sebanyak tiga kali. Faktor pertama adalah konsentrasi minyak sawit (1\%; 2\%; 3\%) v/v dan faktor kedua adalah konsentrasi Tween 20(0,5\%; 1,0\%; 1,5\%) v/v. Parameter penelitian meliputi: laju transmisi uap air, kadar air, ketebalan, kuat tekan, persen pemanjangan, dan kelarutan. Hasil penelitian menunjukkan bahwa perlakuan konsentrasi minyak sawit berpengaruh nyata terhadap ketebalan, persen pemanjangan, laju transmisi uap air, kadar air dan Tween 20 berpengaruh nyata terhadap persen pemanjangan dan kuat tekan. Interaksi kedua perlakuan penelitian ini berpengaruh nyata terhadap ketebalan, persen pemanjangan, dan kelarutan edible film komposit yang dihasilkan. Perlakuan terbaik berdasarkan sifat fisik dan kimia adalah edible film komposit adalah konsentrasi minyak sawit $1 \%(\mathrm{v} / \mathrm{v})$ dan Tween $201 \%(\mathrm{v} / \mathrm{v})$ dengan ketebalan 0,23mm, persen pemanjangan $21,67 \%$, kelarutan $89,9 \%$, laju transmisi uap air $16,80 \%$, kadar 19,28\%, dan kuat tekan 5,53 gf.
\end{abstract}

Kata kunci: Edible film komposit; pati jagung; minyak sawit; Tween 20

\section{ABSTRACT}

The aim of this research was to determine the characteristics of composite edible film based on corn starch with the addition of palm oil and Tween 20. This study used a Factorial Randomized Completely Design with two treatments and three replications for each treatment. The first factor was the concentration of palm oil $(1 \% ; 2 \% ; 3 \%) \mathrm{v} / \mathrm{v}(1$; 2: and $3 \% \mathrm{v} / \mathrm{v})$, the second factor was the concentration of Tween $20(0.5 \% ; 1.0 \% ; 1.5 \%) \mathrm{v} / \mathrm{v}$. The observed parameters includes water vapour transmission rate, water content, thickness, compressive strength, elongation percentage, dan solubility. The results showed that palm oil addition had significant effect on thickness, elongation percentage, water vapour transmission rate, water content, the addition of Tween 20 had significant effect on the elongation percentage and compressive strength. The interaction between palm oil and the Tween 20 addition had significant effect on thickness, elongation percentage, and solubility. The optimum treatment based on physical and chemical charateristics of composite edible film was palm oil concentration of $1 \%$ and Tween 20 of $1 \%$ with thickness $0.23 \mathrm{~mm}$, elongation percentage $21.67 \%$, solubility $89.9 \%$, water vapour transmission rate $16.80 \%$, water content $19.28 \%$, and compressive strength $5.53 \mathrm{gf}$.

Keywords: Composite edible film; corn starch; palm oil; Tween 20

\section{PENDAHULUAN}

Edible film adalah lembaran tipis dapat dimakan yang terbuat dari biopolimer dan berfungsi sebagai pengemas produk pangan. Pada umumnya ada 3 golongan biopolimer yang sering digunakan yaitu hidrokoloid, lipid, dan komposit. Hidrokoloid merupakan biopolimer memiliki daya kohesif baik terhadap bahan yang dikemasnya, namun mudah ditembus oleh uap air. Hidrokoloid biopolimer yang sering digunakan adalah golongan karbohidrat seperti pati jagung, singkong, gadung, dan ganyong. Menurut Amaliya dan Putri, 2014) pati jagung dapat digunakan sebagai bahan 
pembentuk edible film karena mengandung kadar amilosa $27 \%$ lebih tinggi dibanding pati kentang $22 \%$ dan pati singkong $17 \%$. Selain itu, sifat hidrokopis pati jagung pada RH (Relative Humidity) 50\% lebih rendah yaitu $11 \%$ dibandingkan pati singkong (13\%), beras (14\%), dan kentang (18\%).

Biopolimer lipid memiliki keunggulan sulit ditembus oleh uap air, namun bersifat kaku atau kurang elastis. Golongan lipid yang sering digunakan seperti lilin lebah, asam palmitat, dan minyak sawit. Manab (2008) mengungkapkan bahwa pemanfaatan minyak sawit dalam formulasi edible film berbasis protein dapat menurunkan laju transmisi uap air, namun sifat elastisitas tidak mengalami penurunan.

Komposit adalah edible film yang dibentuk dari gabungan biopolymer hidrokoloid dengan lipida. Gabungan kedua biopolimer ini dalam matrik edible film akan saling melengkapi dan menutupi kelemahan masingmasing biopolimer yang berpengaruh terhadap peningkatan karakteristik Edible film komposit yang dihasilkan (Krochta dkk., 1994). Permasalahan utama edible film komposit adalah homogenisasi biopolimer hidrokoloid dengan lipid, komponen penyusun lipida, dan keseragaman distribusi dipersi dalam matrik edible film (Bertan dkk., 2005; Kroctha dkk., 1994; dan Fabra dkk., 2008). Santoso dkk. (2012) menjelaskan bahwa edible film komposit berbahan pati ganyong (hidrokoloid) dan lilin lebah (lipida) menghasilkan edible film dengan permukaan berbintik-bintik dan kasar serta nilai rerata laju transmisi uap air dan persen pemanjangan tidak memenuhi standar JIS 1975.

Selain jenis lipid karakteristik edible film komposit juga dipengaruhi oleh jenis surfaktan. Surfaktan berfungsi sebagai jembatan pengikat antara komponen hidrofilik dan hidropobik, oleh sebab itu penentuan jenis surfaktan dan konsentrasi yang digunakan dalam formulasi sangat penting. Pada prinsipnya penentuan surfaktan berdasarkan komposisi formulasi edible film, apabila pada formulasi tersebut lebih banyak mengandung komponen hidrofilik maka surfaktan yang dipilih harus mempunyai nilai hydrophilic-hydrophobic balance (HLB) yang tinggi dan sebaliknya (Santoso, 2011). Salah satu surfaktan yang memiliki bersifat hidrofilik nonionik adalah Tween 20 dengan HLB 16,7 dan viskositas 400 mPa (Fennema, 1996).

\section{METODE PENELITIAN}

\section{Bahan dan Alat}

Bahan-bahan yang digunakan: aquadest, gliserol, Hydroxypropyl Methylcellulose (HPMC), minyak sawit (fraksi olein), pati jagung, dan Tween 20. Alat-alat yang digunakan: hot plate merk Torrey Pines Scientific, Neraca analitik (merk Ohaus corp. Pine Brook, N.J. USA), pompa vakum (model; DOA-P504-BN), magnetic stirrer, vortex, oven, inkubator, desikator, Haze meter seri NDH-200 buatan Nipon Denshoku Kogyo Co Ltd, micrometer(Roch) (A281500504, Sisaku SHO Ltd, Japan), Testing Machine
MPY (Type: PA-104-30, Ltd Tokyo, Japan), water vapor transmission rate tester Bergerlahr.

\section{Rancangan Percobaaan}

Penelitian ini menggunakan Rancangan Acak Lengkap Faktorial (RALF) dengan dua faktor. Faktor pertama yaitu konsentrasi minyak sawit $(A)$ yang terdiri 3 taraf, meliputi: $A_{1}=1 \%, A_{2}=2 \%, A_{3}=3 \%(v / v)$. Faktor kedua adalah Tween 20 (B) yang terdiri dari 3 taraf, meliputi: $B_{1}=0,5 \%, B_{2}=1,0 \%, B_{3}=1,5 \%(v / v)$.

\section{Pembuatan Edible Film Komposit}

Pembuatan edible film komposit mengacu metode Santoso (2011) yang ditelah dimodifikasi. Pati jagung sebanyak $5 \mathrm{~g}$ dimasukkan dalam Beaker glass dan ditambahkan aquadest sampai batas $100 \mathrm{~mL}$, suspensi pati jagung diaduk dengan magnetic stirrer pada kecepatan 8 dan dipanaskan di atas hot plate pada suhu $60{ }^{\circ} \mathrm{C}$ sampai terjadi gelatinisasi. HPMC sebanyak $1,6 \mathrm{~g}$ dilarutkan dalam air panas sebanyak $80 \mathrm{~mL}$ per $100 \mathrm{~mL}$ suspensi pati jagung dan ditambah gliserol sebanyak $3 \%$ dengan suhu yang dipertahankan. Suspensi pati jagung yang telah ditambahkan gliserol dicampurkan dengan gel HPMC pada suhu $60^{\circ} \mathrm{C}$ dan diaduk sampai homogen hingga terbentuk gelatinisasi sempurna. Penambahan Tween 20 sebanyak (0,5\%; 1,0\%; dan 1,5\%)v/v 100 $\mathrm{mL}$ dan selanjutkan minyak sawit sebanyak $(1 \% ; 2 \%$; $3 \%$ ) $v / v$ dengan proporsi berdasarkan jumlah pati. Setelah tercampur homogen dan terjadi gelatinisasi sempurna dilakukan pengurangan udara dalam larutan menggunakan pompa vakum (degassing) selama 1 jam lalu dituang dalam cawan petri yang memiliki diameter $15 \mathrm{~cm}$ sebanyak $30 \mathrm{~mL}$. Suspensi dikeringkan dalam oven pada suhu $45^{\circ} \mathrm{C}$ selama 24 jam. Edible film dilepas dari cetakan kemudian dimasukan dalam desikator selama 24 jam selanjutnya edible film siap untuk dianalisis.

\section{Karakteristik Edible Film Komposit}

\section{Laju transmisi uap air (ASTM, 1997)}

Laju transmisi uap air edible film komposit ( $\mathrm{g} . \mathrm{m}^{-}$ 2.hari ${ }^{-1}$ ) diukur dengan metode cawan yang ditentukan secara gravimetric menurut metode ASTM E96-01. Sebelum diukur, edible film dipotong dengan bentuk lingkatan dengan diameter 37-38mm (sesuai diameter permukaan cawan), ketebalan film diukur menggunakan mikrometer, kemudian dikondisikan dalam ruangan bersuhu $25^{\circ} \mathrm{C}$, RH 75\% selama 24 jam.

\section{Kadar air (AOAC, 2005)}

Cawan aluminium dimasukkan dalam oven selama 30 menit dan didinginkan dalam desikator selama 15 menit kemudian ditimbang berat cawannya. Sampel sebanyak $\pm 2 \mathrm{~g}$ dan dimasukkan ke dalam cawan yang telah diketahui beratnya. Sampel dikeringkan dengan oven pada suhu $105^{\circ} \mathrm{C}$ selama satu malam (12 jam). Sampel beserta cawan dipindahkan ke dalam desikator selama 15 menit, kemudian sampel beserta cawan ditimbang. 
Sampel kering didinginkan dengan desikator selama 15 menit kemudian ditimbang hingga beratnya konstan, apabila tidak ada penurunan berat sampel pada beberapa kali penimbangan setelah pemanasan. Kadar air sampel ditentukan dari berat air yang menguap. Persen kadar air dapat dihitung menggunakan Persamaan 1.

$$
\text { Kadar air }(\%)=\frac{\text { berat awal }(\mathrm{g}) \text {-berat akhir sampel }(\mathrm{g})}{\text { berat awal sampel }(\mathrm{g})} \times 100 \%
$$

\section{Ketebalan (ASTM, 1997)}

Pengukuran ketebalan edible film komposit dilakukan dengan menggunakan micrometer manual dengan ketelitian $0,001 \mathrm{~mm}$. Nilai ketebalan yang didapat merupakan rerata dari pengukuruan pada 5 titik posisi acak.

\section{Kuat tekan (ASTM, 1997)}

Kuat tekan ditentukan jenis probe yang akan digunakan untuk edible film komposit yaitu jenis TA 760 $\mathrm{mm}$ dan digunakan blade pada pengujian kuat tekan edible film. Alat LFRA tekxture analyzer diatur menjadi Test: Cycle count, trigger: $2 \mathrm{~g}$, distance: $0,2 \mathrm{~mm}$, dan speed: $2 \mathrm{~mm} / \mathrm{s}$. Probe dipasang pada tempatnya dan tombol "start" ditekan untuk memulai menekan edible film komposit. Sampel edible film yang telah dipotong dengan ukuran $5 \times 2 \mathrm{~cm}$ ditaruh dibawah probe dan probe akan menekan film sampai besaran gaya probe yang digunakan tampil pada layar. Besar gaya probe yang digunakan untuk menekan sampel akan muncul pada layar dengan satuan ( g.mm. $\mathrm{s}^{-2}$ ) dikonversikan menjadi $\left(\mathrm{kg} \cdot \mathrm{m} \cdot \mathrm{s}^{-2}\right.$ ) atau (N). Kuat tekan edible film dihitung dengan menggunakan rumus kuat tekan (Persamaan 2).

Kuat tekan edible film $=\frac{F}{A}$

Keterangan: $\mathrm{F}=$ Gaya dan $\mathrm{A}=$ Luas permukaan sampel $\left(\mathrm{m}^{2}\right)$

\section{Persen pemanjangan (ASTM, 1997)}

Persen pemanjangan diukur menggunakan Testing Machine MPY (Type: PA-104-30, Ltd Tokyo, Japan) dengan metode standar ASTM D882-02.

\section{Kelarutan (Laohakunjit dan Noomhorm, 2004)}

Edible film $1 \mathrm{~g}$ dilarutkan dalam $10 \mathrm{~mL}$ desilat dengan mengaduk dengan menggunakan magnetic stirrer pada kecepatan skala 8 selama 30 menit. Larutan disentrifugasi pada $3000 \mathrm{rpm}$ selama 15 menit. Bagian supernatan dibuang dan film yang tidak larut dikeringkan dengan oven pada suhu $80^{\circ} \mathrm{C}$ selama 24 jam. Kelarutan edible film dalam air dihitung berdasarkan Persamaan 3.

$$
\% \text { kelarutan }=\frac{a-b}{a} \times 100 \%
$$

Keterangan: $a=$ berat awal sampel $(g)$ dan $b=$ berat sampel sisa yang tidak larut $(\mathrm{g})$

\section{Analisis Statistik}

Analisis statistik menggunakan rancangan acak kelompok faktorial yang dikerjakan menggunakan program SAS versi windows 9. Data yang diperoleh dianalisa keragamannya (Anova). Perlakuan yang berpengaruh nyata akan dilanjutkan dengan uji Beda Nyata Jujur (BNJ) 5\%.

\section{HASIL DAN PEMBAHASAN}

\section{Laju Transmisi Uap Air (LTUA)}

Laju transmisi uap air merupakan slope dari hubungan jumlah uap air yang melakukan transmisi dibagi dengan waktu. Laju transmisi uap air edible film komposit yang dihasilkan berkisar $7,83-16,87 \mathrm{~g} \cdot \mathrm{m}^{-2}$.hari 1. Hasil penelitian menunjukkan bahwa tidak terjadi interaksi antara perlakuan minyak sawit dengan Tween 20. Laju transmisi uap air edible film komposit semakin menurun dengan bertambahnya konsentrasi minyak sawit (Tabel 1). Hal ini disebabkan minyak sawit merupakan golongan lipida mengandung asam lemak tidak jenuh yang bersifat hidropobik. Edible film komposit yang bersifat hidropobik sulit untuk ditembus uap air. Menurut Kroctha dkk. (1994) edible film yang terbuat dari komponen lipida memiliki laju tranmisi uap air rendah tetapi kaku atau tidak elastis. Asam lemak tak jenuh rantai panjang dalam larutan edible film dapat menurunkan nilai WVP karena sifat hidrofobisitas meregulasi komposisi asam lemak dalam edible film sehingga dapat meningkatkan mobilitas struktur edible film (Tanaka dkk., 2001).

Tabel 1. Uji BNJ pengaruh konsentrasi minyak sawit terhadap laju transmisi uap air dan kadar air edible film komposit

\begin{tabular}{ccc}
\hline $\begin{array}{c}\text { Konsentrasi } \\
\text { minyak sawit } \\
(\% \mathrm{v} / \mathrm{v})\end{array}$ & $\begin{array}{c}\text { Laju transmisi uap } \\
\text { air }\left(\mathrm{g} \cdot \mathrm{m}^{-2} \cdot \text { hari }^{-1}\right)\end{array}$ & Kadar air (\%) \\
\hline $\mathrm{A}_{1} 1$ & $15,80 \pm 1,24 \mathrm{a}$ & $19,53 \pm 1,96 \mathrm{a}$ \\
$\mathrm{A}_{2} 2$ & $12,08 \pm 0,73 \mathrm{~b}$ & $15,91 \pm 1,14 \mathrm{~b}$ \\
$\mathrm{~A}_{3} 3$ & $9,59 \pm 1,84 \mathrm{c}$ & $11,13 \pm 1,17 \mathrm{c}$ \\
\hline Keterangan: Angka-angka yang dikuti oleh huruf yang sama pada
\end{tabular}

Keterangan: Angka-angka yang dikuti oleh huruf yang sama pada kolom yang sama menunjukkan berbeda tidak nyata $(a=0.05)$

Peningkatan jumlah konsentrasi Tween 20 dalam formulasi edible film komposit tidak berpengaruh terhadap laju transmisi uap air edible film. Hal ini disebabkan Tween 20 merupakan surfaktan yang meningkatkan kestabilan partikel yang terdispersi dan mengontrol formula matrik edible film komposit. Diketahui bahwa matrik edible film ini terbentuk dari fase yang berbeda yaitu pati yang merupakan komponen hidrokoloid dan minyak sawit merupakan komponen hidropobik, sehingga untuk menjaga kestabilan matrik edible film diperlukan surfaktan. Penggunaan Tween 20 disebabkan fase hidrokoloid lebih besar dibanding fase hidropobik dalam formulasi edible film komposit, sehingga penggunaan surfactant Tween 20 dengan nilai HLB 16,7 lebih tepat. 


\section{Kadar Air}

Kadar air edible film yang dihasilkan berkisar antara 9,89-21,61\%. Perlakuan konsentrasi minyak sawit $1 \%$ dengan Tween 20 1,5\% menghasilkan edible film komposit dengan kadar air tertinggi sedangkan perlakuan terendah adalah konsentrasi minyak sawit 3\% dengan Tween 200,5\%. Analisis keragaman menunjukan bahwa konsentrasi minyak sawit berpengaruh terhadap kadar air edible film komposit, namun konsentrasi Tween 20 tidak berpengaruh. Hasil uji BNJ (Tabel 1) memperlihatkan bahwa makin tinggi konsentrasi minyak sawit maka akan dihasilkan edible film komposit dengan kadar air yang makin rendah. Hal ini dikarenakan minyak sawit yang bersifat hidrofobik (non polar) akan sukar berikatan dengan air dalam formula edibel film komposit, sehingga secara logika air akan terikat secara lemah, dan pada saat pengeringan edible film maka air mudah menguap, hal inilah yang menyebabkan pernurunan kadar air. Selain itu, penurunan kadar air edible film komposit ini juga disebabkan proporsi minyak yang lebih banyak dibandingkan air dalam formula edible film komposit.

Peningkatkan konsentrasi Tween 20 tidak berpengaruh terhadap kadar air edible film komposit. Hal ini dikarenakan sifat surfaktan adalah menurunkan tegangan permukaan, tegangan antar muka, meningkatkan kestabilan partikel yang terdipersi dan mengontrol formulasi minyak dalam air. Selain itu surfaktan juga akan terserap ke dalam permukaan partikel minyak atau air sebagai penghalang yang akan mengurangi atau menghambat penggabungan dari partikel yang terdispersi.

\section{Ketebalan}

Nilai rata-rata ketebalan edible film komposit yang dihasilkan berkisar antara 0,21-0,35 mm hal ini dapat dilihat pada Gambar 1. Nilai ketebalan terendah pada perlakuan $A_{1} B_{3}$ dan tertinggi $A_{3} B_{3}$. Edible film komposit yang dihasilkan memenuhi standar Japan International Standard (JIS) 1975 yaitu maksimal 0,25 mm.

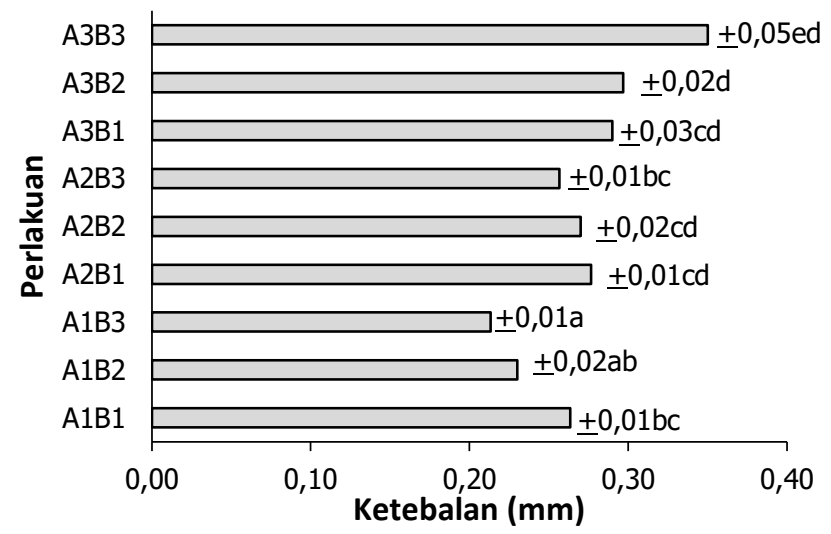

Keterangan: $A_{1}=$ minyak sawit $1 \%(v / v), A_{2}=$ minyak sawit $2 \%(v / v)$, $\mathrm{A}_{3}=$ minyak sawit $3 \%(\mathrm{v} / \mathrm{v}), \mathrm{B}_{1}=$ Tween $200,5 \%(\mathrm{v} / \mathrm{v}), \mathrm{B}_{2}=$ Tween 20 $1,0 \%(\mathrm{v} / \mathrm{v})$, dan $\mathrm{B}_{3}=$ Tween $2015 \%(\mathrm{v} / \mathrm{v})$. Apabila diikuti huruf yang sama pada masing-masing bar menunjukkan berbeda tidak nyata $(\mathrm{a}=$ $0,05)$

Gambar 1. Ketebalan edible film komposit pada berbagai interaksi minyak sawit dengan Tween 20
Ketebalan edible film terendah pada perlakuan $\mathrm{A}_{1} \mathrm{~B}_{3}$ dengan ketebalan $0,21 \mathrm{~mm}$ dan tertinggi $A_{3} B_{3}$ dengan ketebalan 0,35 mm (Gambar 1). Hal ini disebabkan konsentrasi minyak sawit 3\% dan surfaktan Tween 20 sebesar $1,5 \%$ menunjukkan bahwa semua gugus hidrofobik dari minyak sawit berikatan secara sempurna dengan gugus hidrofobik dari surfaktan Tween 20. Formulasi matrik edible film ini terdiri atas 2 fase yang berbeda sifatnya. Pati jagung, gliserol, dan HPMC merupakan fase hidrofilik atau bersifat polar sedangkan minyak sawit adalah fase hidropobik atau non polar. Sehingga untuk membentuk matrik edible film yang stabil harus ditambahkan surfaktan yaitu Tween 20 dengan nilai HLB 16,7 yang memiliki dua sifat bagian kepala bersifat hidrofilik dan bagian ekor bersifat hidropobik. Ikatan yang terbentuk pada matrik edible film komposit adalah pati jagung, gliserol, dan HPMC akan saling berikatan membentuk ikatan komplek dalam matrik edible film komposit karena ketiga senyawa ini memiliki sifat yang sama dan gugus yang bebas dari ikatan komplek ini akan berikatan dengan Tween 20 pada bagian hidrofilik dan bagian hidropobik akan berikatan dengan asam lemak tidak jenuh yang terdapat dalam minyak sawit. Ikatan komplek pati jagunggliserol-HPMC-Tween 20-minyak sawit berpengaruh terhadap pertambahan total padatan matrik edible film komposit. Makin tinggi total padatan maka makin meningkatkan ketebalan edible film komposit yang dihasilkan. Praseyaningrum dkk. (2010) menjelaskan apabila campuran edible film berisi komposisi yang maksimal dari bahan maka akan diperoleh larutan yang sangat kental dan memiliki ketebalan yang lebih tinggi dibanding komposisi yang lain. Menurut Debeaufort dkk. (1995) penambahan trigliserida akan meningkatkan ketebalan edible film dari 0 sampai $60 \mu \mathrm{m}$. Ketebalan edible film komposit makin meningkat dengan makin meningkatkan rasio pati kentang dengan monogliserida (Petersson dan Standing, 2005).

\section{Kuat Tekan}

Kuat tekan menggambarkan gaya tekan maksimum yang dapat ditahan oleh sebuah edible film komposit (Santoso, 2011). Nilai rata-rata kuat tekan edible film komposit pada penelitian ini berkisar antara 2,47-5,53gf. Hasil analisis keragaman menunjukkan bahwa Tween 20 berpengaruh terhadap kuat tekan edible film komposit. Hasil uji BNJ pengaruh konsentrasi Tween 20 terhadap kuat tekan edible film komposit seperti pada Tabel 2 .

Tabel 2. Uji BNJ pengaruh konsentrasi Tween 20 terhadap kuat tekan edible film komposit

\begin{tabular}{cc}
\hline $\begin{array}{c}\text { Konsentrasi Tween } 20 \\
(\% \mathrm{v} / \mathrm{v})\end{array}$ & Kuat tekan (gf) \\
\hline $\mathrm{B}_{1} 0,5$ & $3,38 \pm 1,53 \mathrm{a}$ \\
$\mathrm{B}_{2} 1,0$ & $5,38 \pm 1,44 \mathrm{~b}$ \\
$\mathrm{~B}_{3} 1,5$ & $3,19 \pm 1,11 \mathrm{a}$ \\
\hline
\end{tabular}

Keterangan: Angka-angka yang dikuti oleh huruf yang sama pada kolom yang sama menunjukkan berbeda tidak nyata $(a=0,05)$ 
Uji lanjut BNJ (Tabel 2) menunjukkan bahwa Tween 20 dengan konsentrasi $1 \%(\mathrm{v} / \mathrm{v})$ menghasilkan kuat tekan edible film komposit tertinggi. Hal ini dapat dijelaskan bahwa Tween 20 dengan $1 \%$ dapat menjadi pengemulsi yang tepat formulanya antara pati jagung (hidrokoloid) dengan minyak sawit (lipida). Dengan konsentrasi Tween 20 yang tepat maka yang terbentuk matrik edible film komposit yang kuat, rapat, dan padat. Hal ini berpengaruh terhadap peningkatan kekuatan tekan edible film komposit. Santoso (2011) menjelaskan bahwa penggunaan surfaktan dengan konsentrasi dan jenis yang tepat akan mempengaruhi homogenitas suspensi film yang terbentuk. Suspensi film yang homogen akan menghasilkan edible film yang rapat, padat dan rata sehingga berpengaruh terhadap sifat mekanis edible film.

Minyak sawit mengandung asam lemak tidak jenuh berbentuk cair pada suhu kamar. Asam lemak tak jenuh memiliki mobilitas yang baik dari ikatan rangkapnya sehingga asam lemak tidak jenuh menyebar merata dalam matrik edible film komposit. Hal ini tidak berpengaruh terhadap kuat tekan, namun berpengaruh terjadi penurunan laju transmisi uap air. Edible film yang mengadung lipida memiliki kelemahan sifat rapuh dan tidak elastis (Krotha dkk., 1994).

\section{Persen Pemanjangan}

Persen pemanjangan edible film komposit yang diperoleh berkisar antara 4,67-23,33\%. Persen pemanjangan edible film komposit yang dihasilkan belum memenuhi standar JIS 1975 (minimal persen pemanjangan edible film 70\%). Nilai rata-rata persen pemanjangan edible film komposit disajikan pada Gambar 2.

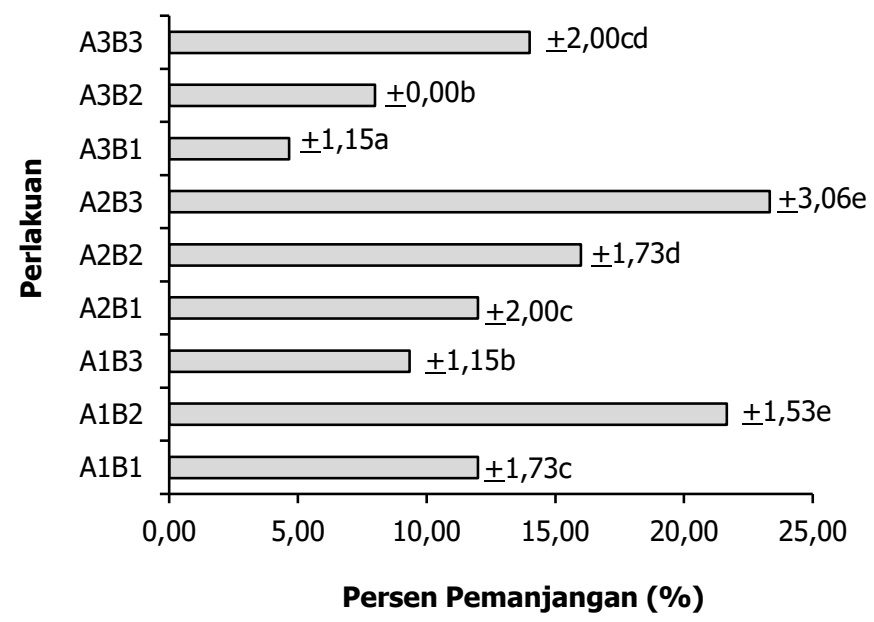

Keterangan: $A_{1}=$ minyak sawit $1 \%(v / v), A_{2}=$ minyak sawit $2 \%(v / v)$, $\mathrm{A}_{3}=$ minyak sawit $3 \%(\mathrm{v} / \mathrm{v}), \mathrm{B}_{1}=$ Tween $200,5 \%(\mathrm{v} / \mathrm{v}), \mathrm{B}_{2}=$ Tween $201,0 \%(\mathrm{v} / \mathrm{v})$, dan $\mathrm{B}_{3}=$ Tween $2015 \%(\mathrm{v} / \mathrm{v})$. Apabila diikuti huruf yang sama pada masing-masing bar menunjukkan berbeda tidak nyata $(a=0,05)$

Gambar 2. Persen pemanjangan edible film komposit pada berbagai interaksi minyak sawit dengan Tween 20

Nilai rata-rata persen pemanjangan tertinggi terdapat pada perlakuan $A_{2} B_{3}$ dan terendah pada perlakuan $A_{3} B_{1}$. Hal ini disebabkan ikatan komplek dalam matrik edible film komposit pada perlakuan $\mathrm{A}_{2} \mathrm{~B}_{3}$, konsentrasi Tween 20 lebih tinggi dibanding minyak sawit. Hal ini menyebabkan pengaruh Tween 20 lebih dominan dibanding pengaruh minyak sawit dalam matrik edible film komposit. Diketahui bahwa Tween 20 merupakan surfaktan dengan nilai HLB 16,7 yang bersifat lebih dominan hidrofilik dibanding hidropobik. Makin tinggi senyawa hidrofilik persen pemanjangan makin tinggi. Menurut Villalobos dkk. (2006) mengungkapkan penggunaan Tween 20 dalam formulasi edible film pati kentang dapat meningkatkan persen pemanjangan sebesar $250 \%$. Rodriguez dkk. (2006) menambahkan bahwa mengkombinasikan beberapa jenis surfaktan, yaitu Tween 20, span 80, dan soy lechitin pada pembuatan edible film komposit pati kentang dengan gliserol sebagai plasticizer. Hasil penelitian ini menunjukkan bahwa ketiga jenis surfaktan mempunyai pengaruh yang sama seperti gliserol terhadap karakteristik edible film pati kentang yang dihasilkan. Dengan adanya penambahan plasticizer ikatan gugus $\mathrm{OH}$ pada matrik dapat dikurangi dan mobilitas rantai polimer matrik akan meningkat sehingga edible film akan menjadi lebih elastis.

Sebaliknya interaksi perlakuan $A_{3} B_{1}$, ikatan komplek matrik edible film komposit senyawa komponen minyak lebih dominan, sehingga persen pemanjangan edible film komposit paling rendah. Minyak sawit merupakan golongan lipida makin tinggi konsentrasi minyak sawit maka makin rendah persen pemanjangan edible film komposit. Jimenez dkk. (2010) menjelaskan bahwa edible film yang dibentuk dari hidroksipropil metilselulosa (HPMC) dengan asam lemak jenuh dan asam lemak tidak jenuh dapat membentuk edible film dengan laju transmisi uap air rendah, namun lebih rapuh atau mudah retak, kurang elastis, warna agak buram, dan kurang mengkilap.

\section{Kelarutan}

Kelarutan edible film komposit yang dihasilkan antara 49,14-89,80\% dan dapat dilihat pada Gambar 3.

Analisis keragaman menunjukkan bahwa perlakuan interaksi konsentrasi minyak sawit dengan Tween 20 berpengaruh nyata. Perlakuan interaksi $\mathrm{A}_{1} \mathrm{~B}_{2}$ menghasilkan edible film komposit dengan tingkat kelarutan paling, perlakuan interaksi ini berbeda tidak nyata dengan $A_{1} B_{3}$. Hal ini disebabkan ikatan komplek pati jagung-gliserol-HPMC-Tween 20-minyak sawit membentuk matrik edible film komposit yang didominasi sifat hidrofilik, sehingga mengakibatkan kelarutan edible film komposit meningkat. Diketahui bahwa Tween 20 merupakan surfaktan nilai HLB 16,7 lebih dominan hidrofilik dibanding hidropobik. Sebaliknya perlakuan interaksi $\mathrm{A}_{3} \mathrm{~B}_{2}$ menghasilkan edible film komposit dengan kelarutan terendah. Hal ini disebabkan formula edible film komposit $\mathrm{A}_{3} \mathrm{~B}_{2}$ mengandung minyak sawit lebih banyak sehingga kelarutan edible fil $m$ komposit menjadi rendah. 


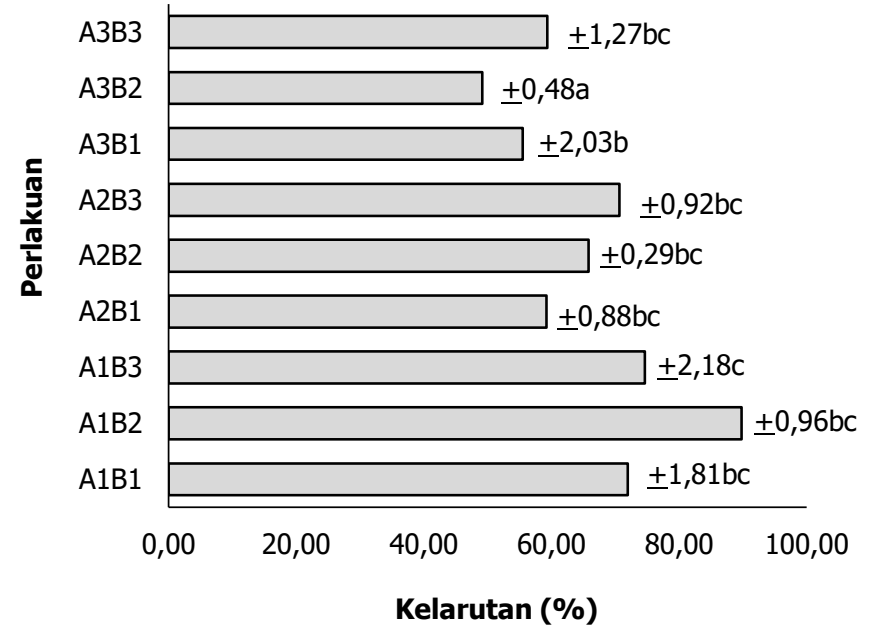

Keterangan: $A_{1}=$ minyak sawit $1 \%(v / v), A_{2}=$ minyak sawit $2 \%(v / v)$, $\mathrm{A}_{3}=$ minyak sawit $3 \%(\mathrm{v} / \mathrm{v}), \mathrm{B}_{1}=$ Tween $200,5 \%(\mathrm{v} / \mathrm{v}), \mathrm{B}_{2}=$ Tween 20 $1,0 \%(\mathrm{v} / \mathrm{v})$, dan $\mathrm{B}_{3}=$ Tween $2015 \%(\mathrm{v} / \mathrm{v})$. Apabila diikuti huruf yang sama pada masing-masing bar menunjukkan berbeda tidak nyata $(\mathrm{a}=$ $0,05)$

Gambar 2. Kelarutan edible film komposit pada berbagai interaksi minyak sawit dengan Tween 20

\section{KESIMPULAN}

Konsentrasi minyak sawit berpengaruh terhadap laju transmisi uap air dan kadar air dan Tween 20 berpengaruh terhadap kuat tekan edible film komposit yang dihasikan. Interaksi antara konsentrasi minyak sawit dengan Tween 20 berpengaruh terhadap ketebalan, persen pemanjangan, dan kelarutan edible film komposit yang dihasilkan. Edible film terbaik diperoleh pada perlakuan $\mathrm{A}_{1} \mathrm{~B}_{2}$ (minyak sawit $1 \%(\mathrm{v} / \mathrm{v}$ ) dengan Tween $201 \%(\mathrm{v} / \mathrm{v})$ ) dengan ketebalan 0,23 mm, persen pemanjangan $21,67 \%$, kelarutan $89,9 \%$, laju transmisi uap air $16,80 \%$, kadar 19,28\%, dan kuat tekan 5,53 gf.

\section{UCAPAN TERIMA KASIH}

Penelitian ini merupakan bagian dari hasil penelitian Unggulan Kompetitif yang dibiayai dari anggaran DIPA Badan Layanan Umum Universitas Sriwijaya tahun anggaran 2017 No.042.01.2.400953/2017 tanggal 5 Desember 2017 dengan Kontrak No 988/UN9.3.1/PP/2017 tanggal 21 Juli 2017.

\section{DAFTAR PUSTAKA}

Amaliya, R. R., dan Putri, W. D. R. (2014). Characterization Edible Film of corn starch with the addition of white saffron filtrateas antibacterial. Jurnal Pangan dan Agroindustri 2(3), 43-53.

American Society for Testing and Materials (ASTM). (1997). Annual book of ATSM standards. USA ATSM, Philadelphia.

AOAC. 2005. Official Methods of Analysis. Association of Official Analytical Chemist. Washington DC.

Bertan, L.C., Tanada-Palmu, P.S., Siani, A.C., dan Grosso, C.R.F. (2005). Effect of fatty acids and 'Brazilian elemi' on composite films based on gelatin. Food Hydrocolloids 19(1):73-82.

Debeaufort, F. dan Voilley, A. (1995). Effect of surfactants and drying rate on barrier properties of emulsified edible films. International Journal Food Science Technology $\mathbf{3 0}$ 183-190.

Fabra, M. J., Talens, P., dan Chiralt, A. (2008). Tensile properties and water vapor permeability of sodium caseinate films containing oleic acid-beeswax mixtures. Journal Food Engineering 85: 393-400.

Fennema, O.R. 1996. Food Chemistry, Third Edition. Marcel Dekker, Inc. New York-Basel-Hongkong. 1067p.

Jimenez, A., Fabra, M.J., Talens, P., dan Chiralt. (2010). Effect of lipid self-association on the microstructure and physical properties of hydroxypropyl-methylcellulose edible films contaning fatty acids. Carbohydrate Polymer 82: 585-593.

Krochta, J.M. Baldwin, E.A., dan Nisperos-Carriedo, M.O. (1994). Edible Coatings and Film to Improve Food Quality. Technomic. Publi. Co. Inc. USA.

Laohakunjit. N dan A. Noomhorm. (2004). Effect of plasticizer on mechanical and barrier properties of rice starch Film. Journal Food Science 56(2), 348-356.

Manab, A. (2008). Pengaruh penambahan minyak kelapa sawit terhadap karakteristik edible film protein whey. Jurnal IImu dan Teknologi Hasil Ternak 3(2):8-16.

Petersson, M. dan Standing, M. (2005). Water vapour permeability and mechanical properties of mixed starch monoglyceride films and effect of film forming condition. Food Hydrocolloids 19:123-132.

Rodriguez, M., Oses, J., Ziani, K., dan Mate, J.I. (2006). Combined effect of plasticizers and surfactants on the physical properties of starch based edible films. Food Research Internationa/ 39: 840-846.

Santoso, B., Pratama, F., Hamzah, B., dan Pambayun, R. (2012). Perbaikan sifat mekanik dan laju transmisi uap air edible film dari pati ganyong termodifikasi dengan menggunakan lilin lebah dan surfaktan. Jurnal Agritech 32(1): 9-14.

Santoso, B. (2011). Integrasi pati termodifikasi, surfaktan, protein, dan katekin pada pembuatan edible film. Disertasi Program Studi Ilmu Industri Pertanian Program Pascasarjana Universitas Sriwiya, Palembang.

Tanaka, M., Ishizaki, S., Suzuki, T., dan Takai, R. (2001). Water Vapor Permeability of Edible Films Prepared from Fish Water Soluble Proteins as Affected by Lipid Type. Journal of Tokyo University of Fisheries 87: 31-37.

Villalobos, R., Hernandez-Munoz, P., dan Chiralt, A. (2006). Effect of surfactants on water and barrier properties of hydroxypropyl methylcellulose films. Food Hydrocolloid 20: $502-509$. 